\title{
Shaping women: national identity through the use of language in Franco's Spain
}

\author{
MERCEDES CARBAYO-ABENGÓZAR \\ Nottingham Trent University, Clifton Lane, Nottingham NG11 8NS
}

\begin{abstract}
In my article I show how a very particular identity was created for women during the period of Franco's Spain. I will draw upon a varied range of materials from official discourses, particularly the Sección Femenina (the women's branch of Falange); the Álvarez Enciclopedia and other texts such as songs, poems and the popular press.

Following Foucault (1980: 30) I analyse an identity based on oppressive discourses whose power 'reaches into the very grain of individuals, touches their bodies and inserts itself into their actions and attitudes, their discourses, learning process and everyday life'. The nationalistic stress of this discourse is one that encourages women to create a new image of Spanish femininity that should be 'different' from the liberated portrayal of women coming from Europe, mainly through the path of growing tourism.

The language of these discourses is somehow baroque, elaborated, energetic and highly dramatic. It tries to seek attention through an unnecessary and badly misorientated dramatism. It is cryptic and manipulative and claims to be poetical, but its main intention is to confine women indoors and to make them look at the world through the curtains or from a closed window. On the other hand it made women feel they were the representation of a unique matriarchal nationalism making them appear as the heroines of an essentialist national metaphor: women mothers of the nation.

Inherent in Franco's equation of women $=$ femininity $=$ nation is a contradiction that defines women as 'indoor heroines' and bases nationalism in a naturalised representation of gender where women are a gendered representation of this nationalism.
\end{abstract}

\section{Introduction.}

After nine years of dictatorship under General Miguel Primo de Rivera with the blessing of King Alfonso XIII, the Second Republic was proclaimed in Spain on 14 April 1931. A provisional government led by Niceto Alcalá Zamora with republican and socialist representatives came to power peacefully and hopes for change were raised immediately. A truly social change based on agrarian reform and the participation of the working class was expected, together with a strict control of the military and the Catholic 
Church, a solid improvement of the education system and a political answer to the specific problems of Spain. The dream of this project was to change all these things at the same time over a short period (García de Cortázar and González Vesga 1994: 565-6). The Second Republic was a product of new liberalism ${ }^{1}$ that was due in Spain to the work of the Krausists. The Krausists were intellectuals who converted to the doctrines of the German philosopher Karl Friederich Krause. In general terms Krausist ideas looked for social and cultural change. Krausists looked for modernisation of the country through industry, democracy and education. They created the Free Institution of Teaching (Institución Libre de Enseñanza), a revolutionary institution whose methods of learning were based on a concept of pedagogy in which they left aside authoritarian, memory-based and excessively book-oriented techniques, and focused on more active methods. They promoted 'freedom of inquiry and opinion, mutual tolerance and respect, personal morality and religious sincerity, equality and respect between the sexes, artistic sensibility, healthy habits and exercise and indifference to luxury and ostentation' (Boyd 1997: 34). Between 1931 and 1933 a major effort was made to secularise Spanish society, since in political terms the Catholic Church had always been identified with the right and in social terms with the powerful elite. But as Payne (1984: 157) points out, the republican anti-clerical policy reawakened a sense of Catholic identity and, as a consequence, 'it elicited a powerful Catholic resurgence and opposition that was simply non-existent in 1931'.

In 1932 the CEDA (Spanish Confederation of Autonomous Rightist Groups) led by José María Gil Robles was established. Although the CEDA accepted the republican regime and institutions, its Catholic political discourse sought not only to return to the church its former privileges and influence, eroded by anti-clerical legislation, but also to put the interest of the social groups that it represented - that is, rural landowners and industrialists - at the core of the political debate. Such aims became an actual reality during the so-called 'two black years' (bienio negro), the two years of right-wing government after the November 1933 elections. The CEDA was, for the majority of left-wing and democratic political parties, the biggest 'fascist' threat until José Antonio Primo de Rivera, the son of the dictator, created La Falange in 1933. Encouraged by the success of the Nazi Party and convinced that Spain needed to be saved from communism, José Antonio was determined to follow his father's example. In his first speech, in the Teatro de la Comedia de Madrid ${ }^{2}$ on 29 October 1933, he said: 'Our movement is not a way of thinking but a way of being ... If we have to defend this using violence let us use it ... The only admissible dialogue when justice and the Patria are offended is that of fists and guns' (Thomàs 1999: 30-1) (this and other passages are my translation).

Indeed, communism was also rising in Europe. In order to fight the advance of fascism, international communism decided to create Popular Fronts. These Popular Fronts unified the proletariat with the middle classes, the communists and socialists with the anti-fascist bourgeoisie making a 
common front against fascism. In Spain the Popular Front, made up of republicans, socialists, trade unionists and communists, won the elections of February 1936. Its programme did not contain revolutionary measures but, unlike before, all the new projects were immediately approved and applied (Tuñón de Lara 1982a: 123). The new government faced immediate tension, threats and violence between those who supported the new legislation and those who wanted to keep the old traditions. This tension led to General Francisco Franco's coup d'état, the subsequent Civil War and, with the victory of the nationalists, ${ }^{3}$ the period known as Francoism. During this period there was a shift in the discourse of nationalism from the plural to the singular, from the diversity of Catalan, Basque and Galician nationalisms as they were regarded during the years of the Second Republic, to the discourse of Spain as one nation. This shift is related to the dominant ideology of Franco's regime which comprised five forces that were knows as the 'families' (familias) (Payne 1992: 10): the falangists, the army, the monarchist, the carlists and the right-wing Catholics. For the purpose of this article, when I refer to the term 'nationalism' during Franco's regime I identify it with this ideology.

La Falange, despite a number of ups and downs, continued its role as one of the main contributors to the ideology of Franco's regime until 1975. After the death of Franco, it seemed to have lost its ideological significance. In 1974, confronted by crisis, the falangist Raimundo Fernández Cuesta (1974: 2) said: 'They want to wipe out the Falange from our political horizon as though it were a black storm cloud that obscures and eclipses the radiant sun of their yearning for democracy' (my translation). In the same article, Fernández Cuesta explains what the Falange was and why it was still relevant for the Spain of the 1980s. According to him, the Falange came into being as a result of the inability of both capitalism and communism to solve people's problems. It was based upon a concept of Christian humanism, eternal values, the unity of Spain and national syndicalism (otherwise known as vertical syndicalism). The falangists wanted to substitute the idea of vindication for participation since, according to them, revindication assumed a situation of inferiority, whereas participation implied equality. People's representation was to be achieved through the process of the following institutions: family, town and syndicalism. Finally, for Fernández Cuesta (1974: 1), 'Falangism is made up of both a romantic lyricism and classical norms. It is a living reality that generates a shining future' (my translation).

These two quotations are representative of what I am going to discuss in the following pages, namely a cultural narrative, a very specific discourse that I have christened 'baroque' (Carbayo-Abengózar 1998: 41). The baroque discourse is one that is based on authoritarianism as opposed to liberalism, Catholic principles as opposed to non-Catholic ones, and is focused on keeping one's own traditions as opposed to being open to new ideas. It is a very passionate and powerful discourse. As Foucault identifies it, it is a discourse that 'reaches into the very grain of individuals, touches their bodies 
and inserts itself into their actions and attitudes, their discourses, learning process and everyday life' (Foucault 1980: 30). It is a discourse based on the three 'Ps' of baroquism, namely Poetry, Purity and Patria. Poetry refers directly to the baroque style, in the intensity, expressiveness, sentimentalism and hyperbole of the lyrics of texts used by the Falange. As examples of poetry, take these descriptions of the falangist Fernández Cuesta: "black storm cloud that obscures and eclipses the radiant sun of their yearning for democracy' (1974: 2) or 'Falangism is a living reality that generates a shining future' (1974: 1). Poetry was a key word of the Falange from the moment it was created. In the above-mentioned discourse that José Antonio Primo de Rivera gave in the Teatro de la Comedia, he finished by saying: 'I think our flag has been hoisted. Now, let us defend it happily, poetically ... Only poets have ever mobilised people. I pity those who cannot embrace poetry which offers promise and not destruction ... This is a poetic movement' (Thomàs 1999: 33, my translation).

The concern with purity conveys a sense of exclusivity, unity and, as will be shown, virginity. It also refers to religious purity based on the Catholic idea of redemption and the expiation of sin through sacrifice. Patria is a concept that includes the other two entities, and is a symbolic place for both Purity and Poetry. According to José Antonio: 'Patria is a total unity. It cannot be in the hands of the strongest class or the best-organised party. Patria is a transcendental synthesis, an indivisible synthesis' (Thomàs 1999: 30, my translation). This sense of synthesis and unity, which will evolve later as 'Spain, one, great and free', refers to the sense of exclusivity, and subsequently to purity.

It is a narrative that conforms to a specific form of identity, a new form of being Spanish; according to Martín (1995: 13), 'The identity narrative brings forth a new interpretation of the world in order to modify it.'

In the following pages I examine how this new interpretation of the world was being created under the powerful discourse of Francoism and especially how it defined a particular identity for women.

\section{Contextualising women}

Before entering into an analysis of the official narrative created for women during Franco's regime, consider their situation before that period in order to understand the changes that they had to confront.

In the astonishingly short and intense period from 1931 to 1936, Spanish women were able to move from one of the most backward societies and polities in 1930s Europe to become the legal equals of men, they were able to vote and stand for parliament. For the first time, women could get divorced, sign contracts, act as legal witnesses and guardians, and administer estates. The Second Republic opened up public spaces that had previously been closed to women. Women gained public office; examples were Margarita 
Nelken, member of parliament for the PSOE (Spanish Socialist Party), the republican Victoria Kent, who served as director general of the prison service, and the anarchist leader Federica Montseny. Furthermore, from 1931, women were present publicly at the lower levels of the Spanish political hierarchy carrying out tasks that were effectively new for them in the political sphere, in the press, on the radio, in the universities and even in the prisons as political prisoners. According to Kaplan (1992: 315), 'It is noteworthy that the Spanish Second Republic, like the Portuguese Republic earlier, gave women the vote and the status of equality before the law, and permitted divorce. In a whole range of concerns its constitution and legislation attempted to remove the gender bias and the oppression of women.'

However, it should be emphasised that Spain was mainly a rural and very unevenly developed state, and consequently most changes took place in the few urban and industrialised areas. In addition, women were confronted with numerous difficulties in organising themselves, due to a raft of competing issues, and remained a fragmented labour force, with a very low level of education. Even when they managed to join trade unions, women had to confront the incomprehension of the male-dominated bureaucracy (Graham 1995: 101).

In 1934, when fights between left-wingers and falangists became frequent, the women's section, Sección Femenina of the Falange (SF) was created. The aims of this organisation in falangist terms were: ${ }^{4}$ the co-operation of women in the formation of an imperial and greater Spain; the encouragement of a national-syndicalist spirit in all aspects of life, and the promotion of love of the Patria in the fight against what was perceived as an 'anti-Spain'. The Sección Femenina was a hierarchical and authoritarian organisation. It had a national head, a provincial head, a national secretary and a provincial secretary. As women, in their role as mothers, were the surest means of enlargement of the future Spanish empire, they were expected to carry out several tasks. During the Spanish Civil War, their mission did not lie in the actual fighting, but rather in the spreading of propaganda: sewing and embroidering flags and other Spanish symbols; visiting and caring for prisoners and the wounded; carrying guns and batons to meetings, and restricting all contact to falangist men. In the first stages, before Franco's regime, to become a member of the SF a woman needed a minimum educational background. They should have studied in a convent and have had some knowledge of music and languages. Most of them came from the CEDA. The number of affiliated women in 1936 was around 200 in Madrid and another 200 in the rest of Spain. The organisation grew appreciably during the Civil War and the number increased to 600,000 in 1939 (Puga 1969: 194).

When the Spanish Civil War broke out, large numbers of proletarian and middle-classs women were involved in wartime tasks in order to replace men and also to sustain their families while men were absent at the Front. In nationalist Spain - that is to say, the Spain where the 'nationalists' (Francoists 
presented themselves as Spanish nationalists) were winning - there was less industrial mobilisation of women, but under the auspices of the SF, women became very involved in providing different services, such as clinics and launderettes at the Front. As the nationalist cause began to gain ground, these women would give courses on agriculture to rural women, adhering to the notion that the Spanish peasantry embodied the virtues held to be central to their national identity: hardwork, stoicism, a good demeanour, thrift and a readiness to sacrifice themselves for the well-being of the Patria.

In October 1937 the SF created the Servicio Social (SS), first called auxilio de invierno (Winter Aid), based on similar lines to the German Winterhilfe. It had sections that would protect mothers, children, the old and the sick, which included organising homes for them. The SS became a duty for all Spanish women between the ages of seventeen and thirty-five. Its completion was compulsory for every woman who wanted to work or even to get a driving licence. It consisted of six months' state service, of which at least three months constituted unpaid welfare work in hospitals, schools, orphanages, old people's homes, food kitchens, and the making of clothes or trousseaux for babies. Other activities were summer camps for the flechas (girls between eleven and thirteen years old), where they were taught womanly tasks and doctrines. They were instructed in discipline and obedience and learned how to work and participate within the nationalist hierarchy. Indeed, there was a Nazi component in the ideology of women of the SF. Some of them were sent to Germany during the Spanish Civil War to learn from the German women's organisations. There, they followed courses in nutrition, paediatrics and dietetics and also learned about the spirit of nationalsyndicalism of the Nazis. It is very likely that they imported from Germany the obsession with grace, beauty and health that they later imposed on Spanish women, particularly the teenagers they trained in the summer camps mentioned above. It is also likely that they found a new component to the idea of exclusivity and purity of the race, something that would complement the Spanish creation of casticismo, a pure caste or race to the exclusion of all foreign elements. As has been pointed out, these women would restrict all contact to falangist men only. According to Adrian Hastings (1997: 112), Spain and Germany have in common the foundation of their nationalistic doctrines on racial rather than religious principles. There were also similarities to fascist Italy, as Lesley Caldwell (1989: 171) has mentioned, including the role of the Catholic Church in both Spain and Italy: 'There are clearly parallels between fascist rhetoric on motherhood and the church's stress on women as mothers first and foremost.' Clearly, fascism serves as a mirror to other fascisms in terms of sexual policies. In countries where fascist ideology was present, women were seen to have the same destiny: as mothers of a special nation based on a natural-biological conception of race.

After 1939, women were sent back to their homes having lost the political rights and responsibilities they had gained under the Republic. With the 
support of the SF and its intervention to control the material crisis and to manage women's support, the regime was more easily established, women were confined indoors, identified with nature and excluded from the civilised public political domain. It is within this private sphere that women could start to create the 'Spanish man'. The symbolic woman, as represented in the image of the Republica, dressed in white with the republican flag, scales in her hands and a lion at her feet, who waved the republican flag as a symbol of liberty and revolution, was going to contradict the feminine values of respectability and rootedness of the new regime, so she needed to be quickly domesticated.

These attempts at domestication occurred from the very begining of Franco's regime. They were summed up in the words that Pilar Primo de Rivera, the national head of SF, used in her address to Franco and the nationalist victors on 30 May 1939:

In order to celebrate our victory and to honour your soldiers the SF is taking its members out of their homes, because otherwise the only mission that women have in the Patria is to be at home. That is why now that we have peace, we will enlarge the task we started in our training schools. The aim is to make men's family life so agreeable that they will be able to find at home those things which they never had before and therefore they will not need to go to seek it in bars and casinos. We will teach women to take care of their children because it is unforgivable that so many children should die because of the ignorance of their mothers; children that are God's servants and future Spanish soldiers. We will also teach them to take care of the house and to love manual tasks and music. We shall instil in them this 'way of being' that Jose Antonio wanted for all Spaniards so that, when they have children, they can bring them up in the love of God and the falangist way of being. Then, one generation later, thanks to the mother's work, the child who has worn the uniform since day one, and listened, alongside fairy tales, to the story of the war and the Caudillo, and the life and death of Jose Antonio, will grow up to be a real man and will carry within him the appropriate style of our revolution. (Speech at Castle of La Mota cited in García Basauri 1980: 55, my translation)

With these words of Pilar Primo de Rivera in mind, the fascinating and also terrifying world of Franco's Spain will now be considered, below.

\section{Francoist discourse}

None of the previous Spanish political regimes had controlled the role of women in society in such a severe manner. Pilar Primo de Rivera and her SF women, as they had promised in the La Mota Castle, started to train the new Spanish women. Women were therefore going to become the controlling and the controlled. In Foucaulian terms, using the 'dividing practices' as a way of manipulation, women were 'objectified by a process of division either within themselves or from others' (Foucault 1982: 208). In the Spanish case, this process took place in both directions: the division within themselves appeared 
as a result of the imposition to create a 'new' image of women that was going to be very contradictory because, being new, it had to be based on 'old' patterns and traditions. The division from others (non-Spaniards) came with the general idea of autarky and self-sufficiency of the first years of Francoism as a division from the rest of the women outside Spain. The image of new women for the new Spain was a contradictory image in itself in the sense that it was supposed to be new but was in fact based on 'old', traditional, exclusive, religious and national-patriotic values:

The new woman does not have to be either the modern woman - who begins by denying her femininity, avoiding motherhood, being a good friend of her husband, and ends up being a nice colleague and compromising his very virility - or the 'good lady wife', impossible as a mother, bad tempered as a wife and deadly boring as a companion [compañera]. The new woman should be a woman of her times, happy being a mother, bringing up her children, showing a feminine interest in her husband's matters and giving him a quiet refuge amid the problems of public life. In short: cleanly modern. (Scanlon 1986: 324, my translation)

Indeed, cleaning was a real obssesion in the ideology concerning these women. On the one hand there was the cleaning directly related to the body and the house. In the falangist discourse, to be clean and healthy almost became an obsession. In the SF magazine Medina there was plenty of advertising regarding the way in which women should mantain the family's cleanliness. But there were also references to other aspects of life expressed with words related to cleaning:

The life of every woman, despite what she may pretend, is nothing but a continuous desire to find somebody to whom she can succumb. Voluntary dependency, the offering of every minute, every desire and illusion is the most beautiful thing, because it implies the cleaning away of all the bad germs - vanity, selfishness, frivolity - by love. (Semanario de la SF 1944)

By referring to all women and their desire for dependency and by using the term 'bad germs', a word much used in advertising, the desires are manipulated and are kept under control through unconscious associations.

Aside from this, there was a cleaning directly related to the concept of purity, in its sense of exclusivity of the Spanish race, represented in the casticismo mentioned above, which was based upon the determinism of Darwinist biology that influenced the regenerationist ideology at the beginning of the century (Richards 1995: 153). The concept of purity also refers to the exclusivity of a self-sufficient, self-controlled and autarkic vision of the state. As Gisela Brinker-Gabler and Sidonie Smith (1997: 15) point out: 'In times of national trauma, the nation is a masculine body sapped of its lifeblood, corrupted by contaminating influences, weakened, stripped of its independence and autonomy, emasculated. In such times, threats to healthiness and purity of the body politic are identified with the "foreign" 
or "alien" within.' In the most pure, racist and exclusive way, the superiority of Spanish race is based upon the exclusivity of its members:

We want our friends, our servants and our fiancées to be Spanish. We want our children to be Spanish. In our holy Spain we want only our traditions. If you want to call this nationalism, that is fine with me. We do not want progress, the romantic, liberal, capitalist, bourgeois, Jewish, Protestant, atheistic and Masonic Yankee progress. We prefer the backwardness of Spain, our Spain. God bless our backwardness that makes us consider marriage as a sacrament ... the family as a hierarchic society in which the parents have the duty of educating the children in the service of God ... (Castro Villacañas 1948, my translation)

Mantaining the purity of the race and the input on the cleaning of these concepts became the responsibility of women, particularly mothers. That is why mothers were supported from the very beginning, as exemplified in the following quotation that transcribes the words that a falangist doctor, Dr Luque, used in 1938 in another of the SF magazines, $Y$ (García Basauri 1980: 54):

In the state, the woman/mother has to be the most important citizen. Those are the words that Hitler said in his fundamental programme. Because we know he is totally right, and because we are aware of the importance of getting as many healthy children from healthy mothers as we can for our country at this moment, we have to make this statement come true, not only in words but in actions.

He adds that in addition to Germany, Italy and Japan, 'the countries most spiritually linked to Spain', had also done a good job in favouring the mother and child. By 'spiritually linked to Spain' he probably refers to an idealised and stereotypical view of these countries within the falangist rhetoric: anti-American, anti-communist, pro-imperialist and authoritarian. He ends up by using the typical rural metaphor, comparing women with trees and children with fruits and wishing that the harvest, rather than being big (referring to the big families encouraged by the regime), should be healthy.

The Francoist discourse for women was based on a solidly middle-class concept bounded by three parameters: savings, utility and security (Verdú 1986: 75). The concept of savings was based on the idea of holding back or self-restraint. Sexuality was administered through the institution of engagement (noviazgo). To hold back was the highest proof of respect - it was the norm, the law; but the responsibility of keeping it going was placed upon women's shoulders:

If you have not been pure during your engagement, would your eyes be able to hold your children's gaze? Will a forced firmness of words steady the shaking of your soul? Will the innocence of those beloved eyes not well up in your conscience and hurl at you the sinister shout of 'hypocrite'? Girl, do not expose yourself to such a cruel torture. Remain pure during your engagement. Do not become incapable of motherhood ... Tell him all that, when, in a moment of passionate blindness he wants to splash you with mud. (Enciso 1967: 117 and 119, my translation) 
Saving up sexuality brings a reward: a paradisical marriage. The concept of utility plays against desire because there must always be a reason for everything. Relationships must have a goal, which is marriage. Through marriage, women become the arbitrators of order and conformism and they are secure. Engagement is a family institution - therefore it gives security to the couple, but particularly to the woman. Women are naturally suited to the family: reproductive work is natural; therefore the family is a natural entity. This cultural narrative based on a bourgeois morality focuses on normative gender identities and essentialised sexual differences. The use by this narrative of stable bourgeois families in which individuals fill their proper roles for the good of the state is a metaphor for the creation of a powerful nation-state. In this respect, the stability of the nation and its 'proper' functioning depends upon the degree to which the nation's real women embrace the identity (Parker et al. 1992: 6).

This kind of narrative can hardly be regarded as Poetry, but we can see that the three key notions of baroquism as defined earlier are present here. Pilar Primo de Rivera refers in the mentioned discourse to 'the mission that women have in the Patria'. Patria is in itself a contradictory term, since sometimes it is represented as 'fatherland' and some other times as 'motherland'. Women are included and excluded at the same time. The term appears to be, on the one hand, a patriarchal construction made of maleheaded families, based on nationalism as a connotation of tribalism or a family headed by a man, and, on the other, a motherland, a place where, according to Peterson (1996: 7), 'women serve as the symbolic markers of the group's cultural identity'. This contradiction makes the idea of new women and their mission questionable since it is unclear what the position of women is in this discourse. How can women manage, for instance, to express a feminine interest in their husbands' matters avoiding at the same time becoming their friends? Should this friendship be different from brotherhood or fraternity defined by John Hutchinson as a way of 'gathering together in a single historic territory called homeland' (Hutchinson and Smith 1994: 4)? And if it is, how? Are women allowed to be fraternal or just maternal? As George Mosse (1985: 10) points out, the construction of manliness as active and rational and femininity as passive and emotional has been adopted by nationalism since the beginning of the nineteenth century as a foundation on which 'to built its national stereotypes'.

The language in all the passages quoted in the analyses uses highly dramatic expressions such as 'sinister shouting' or 'being splashed with mud'. The narrative is colourful, with diminutives such as chiquitin (little tot) or boastful expressions such as 'real man' in an attempt to interpret the idea that José Antonio had of Poetry, as mentioned before. Some of these expressions are consciously oriented towards making women responsible for the 'burden of representation' (Mercer 1990), since as mothers they had to guarantee the security, ensure the utility and look after the savings of the Patria. The children did not die 'because of the ignorance of their mothers' but for a 
number of other reasons, such as shortages of food and medicine or a poor national health system, and an assumed lack of purity as it seems to suggest the quotation cannot preclude women from becoming mothers.

If we consider identities, as mentioned above, as specific forms of cultural narratives that constitute commonalities and differences between 'self' and 'other', we can interpret Dr Luque's statement as an example of the sort of cultural narrative that was powerfully transmitted and produced in Franco's Spain. It was one that would find common ground with Hitler's Germany, Mussolini's Italy, and probably Japan in terms of organising women, encouraging childbirth and monitoring health and care. But at the same time, it is a different narrative based upon the 'uniqueness' of Spanish identity, the repeated 'way of being' of José Antonio, founded on the myths of common origin and a mythical common destiny. The nationalistic tone of this discourse is one that encouraged women to create a new image of Spanish femininity that should be different from the liberal portrayal of women coming from Europe and thereby make women responsible for keeping their sexuality under control and the country clean and pure. As stated above, women had to co-operate in the formation of an imperial and greater Spain and to fight against the perception of an anti-Spain, opposition that was constantly used to establish a conscious division between people who were pro- and anti- the falangist model of Spain.

\section{Spanish women $=$ Spanish nation}

Against impossible odds, they [women] administer the routine of millions of bleak, hungry and ignorant families. The women of Spain make her a nation. Their daily striving and suffering make what little structure there is. The men of Spain have built a state, but they have never built a society; this can only be found in the hearts and minds and the habits and love and devotion of its women. (Wright 1957: 160) (quoted in Graham and Labanyi 1995)

According to Wright, Spanish women created the Spanish nation and society. Wright's definition of womanhood is made up of habits, love and devotion. Montserrat Guibernau (1996: 47) defines a nation as 'a human group, conscious of forming a community, sharing a common culture, attached to a clearly demarcated territory, having a common past and a common project for the future and claiming the right to rule itself'. Putting together these two definitions, Spanish women under Franco were responsible for defining and then maintaining this shared common culture based on a common past and a common project for the future. This resulted in quite an easy task, thanks to a strongly Catholic-controlled education system in which women, both nuns and SF, could invent a tradition based on a liberating amnesia that rendered all these changes legitimate. Looking into some of the schoolbooks that children and teenagers studied in the 1950s and the 1960s, this is project displayed and explained rigorously. A particularly interesting book is 
Alvarez's Enciclopedia. In Spain most children, including myself, studied it during the 1950s and 1960s. Apart from clearly defining different tasks for women and men in what they called Formación Politico-Social (Political and Social Education), they explained the creation of the Spanish nation - and, further, the Spanish enterprise or Hispanidad - as a mixture of religious, racial, patriotic and gender parameters. Hispanidad is still celebrated in Spain on 12 October, which is also called dia de la raza (the day of the race). 12 October is the saint's day of the Virgin of Pilar, the patron saint of Spain and the army, and the day when Columbus arrived in America for the first time. The día de la Hispanidad or día de la raza celebrates the spiritual union of all Spanish-speaking countries blessed by the Virgin, a feminine figure who according to the Enciclopedia chose Spain as her favourite country, as she established it when she appeared to St James. She protected the Spanish army when it fought for the independence of Spain against Napoleon.

This war of independence produced another woman who became a legend and served as an example for future women of the Patria, Agustina de Aragón. She fought with such bravery during the battle of Zaragoza in 1808 that the French had to withdraw. A second woman, the Catholic Queen Isabel, was used as a prototype of Spanish womanhood and with her royal blessing Spain became the Mother of America. Both women are related to the concept of Hispanidad and both were used to revive a constructed Spanish spirituality, something that the historians Fernando García de Cortázar and José Manuel González Vesga (1994: 420) have come to call 'la marca hispánica'.

The connections between women and the Catholic religion in the interpretation of history have always been based upon the presence of the Virgin Mary as the Mother of God and therefore the mother of the big family which was Spain. According to Manuales Manjón (1940: 179), the embryo of the Patria should be found in the honourable, orderly Catholic family. Recovering traditional Catholic discourse, Francoism strongly emphasised the role that Spain had played in history, so that the future mothers of Spain could transmit the message to their children. Through their families, women are responsible for defending both la Patria and Christian civilisation. In this way they become the foundation of the physical and ideological reproduction of national. The burden or representation for Spanish women of Francoism consisted of an enormous responsibility, as seen throughout this article: the creation of a new image of women, the control of sexual desire, the maintenance of a pure, clean and Christian society and finally the physical and ideological reproduction of new heroes. Nationalism was then focused on women, who were considered to be both part of the system and its victims.

However, as Foucault identifies discourse as powerful in the sense that it is a way of specifying knowledge and truth, he also claims that it is changeable: 'Discourse transmits and produces power; it reinforces it, but also undermines and exposes it, renders it fragile and makes it possible to thwart it' (Foucault 1984: 100). This power cannot be understood in terms of opposition between the oppressor and the oppressed, the ruler and the ruled, but rather 'by means 
of surveillance, by means of a system of levies or obligations distributed over time' (Foucault 1980: 104). Indeed there were different stages of Francoism in which this power was exercised in a different manner or in different terms, and in which the resistance to it was more successful. In the first stages of Francoism, resistance to both the essentialist discourse of women and the discourse of the nation as one in language and culture was more difficult due to the confusion created by the Civil War, the difficulties of restarting in an isolated and wounded country and the fight for survival of the majority of the population: 'in 1950 the average Spanish family ate $39 \%$ of the meat and $57 \%$ of the wheat they had eaten in 1935' (Tuñón de Lara 1982b: 111). In such an authoritarian society it was very difficult to determine what resistance might entail. As seen above, the SF started its work of indoctrination almost immediately. In this respect, women of the SF were used as the surveyors of the regime with regard to womens' issues. Despite the image of peace and happiness that the regime wanted to portray, there were a number of general strikes in Catalonia and the Basque Country during the 1960s as the political opposition began to get organised. It was, however, during the 1960s that the image of Spain was going to change and the different ways of resistance would become more obvious. At the beginning of the 1960s new clandestine political parties had appeared: the FLP (Popular Liberation Front), Frente de Liberación Popular, Social-Democratic Action Party (Partido de Acción Social Democrática) and the Christian Democratic Union Party (Unión Demócrata Cristiana). The Spanish Socialist Workers Party (the PSOE - Partido Socialista Obrero Español) was growing, the Socialist Catalan Movement in Catalonia held its first Congress, and in the Basque Country, ETA (Euskadi ta Azkatasuna, Patria y Libertad) was organised. Regarding womens' issues, between 1960 and 1975 Spanish feminism reappeared from two different positions: from the anti-Francoist movements led by clandestine political parties and from the different Catholic groups that fought for women (Morcillo 1988: 89-90). 1960 saw the appearance of the Seminar of Sociological Studies on Women (Seminario de Estudios Sociológicos sobre la mujer) and in 1964 the Democratic Movement of Women (Movimiento Democrático de Mujeres) was established. Indeed, one of the most important events of the 1960s was the Second Vatican Council in 1962. The outcome of this council shifted the direction of some Catholic organisations, which now began their political actions from the left. In 1963, for the first time in the Francoist period, a high religious figure, Abbot Aureli M. Escarré, abbot of the highly influential Abbey of Monstserrat (Barcelona), spoke publicly in favour of democracy. Around Spain, numerous groups (Catholic Apostolic Social Movement - Movimiento Apostólico Social, and the Young Female Catholic Workers - Juventud Obrera Católica Femenina), imbibed of this new Catholic spirit, participated very actively in the improvement of the living conditions of the poor (Alcalde 1996: 107).

There were also times for changes within the SF. On 22 July 1961, the 'Law of Political and Professional Rights for Women' (Ley de los derechos politicos 
$y$ profesionales de la mujer) was presented to parliament by the SF. This law was an attempt to give women access to professions that had been denied them until then. However, when Pilar Primo de Rivera presented the law, she claimed that it was not at all a feminist law but an attempt to improve professional women's conditions. ${ }^{6}$ In her view, the best place for women was still the home, but since some of them were forced to work, they should do it in equal conditions to men. Domination and categorisation of women by using biology to define them as mainly procreators and by excluding them from the public domain remained in place, but a range of different feminist and political discourses were definitively breaking the monolithic view of the falangists. In the same way that the power of the Francoist discourse had not been unified, there was more than one means of resistance. Apart from the political resistance there was also resistance from the arts, cinema, literature and popular culture - examples of popular music resistance are the songs Se va el caimán ('The alligator is leaving'), in which the alligator appears to represent Franco and the desire for his departure, or Tatuaje ('Tattoo'), which tells the story of a woman searching desperately and endlessly in the bars of a port for her lost sailor lover whose name she bears tattooed upon her arm. This song subverts the narrative of the happily married women working as a housewife and presents the image of a woman living in the marginality of the law, without identity, provocative and full of passion.

In line with Stuart Hall's (1992) assumption that cultural identities are in fact fluid and cross-cutting, Franco tried to elaborate a view of national identity as immutable and pure. In his view, this identity claimed to remain unchangeable over the centuries as an inheritance from the fifteenth and sixteenth centuries when Spain was conceived as a pure empire freed from Muslims and Jews. Aside from this, more modern doctrines such as, on the one hand, protestantism, free-masonry, capitalism and NorthAmericanism ${ }^{7}$ and, on the other hand, anarchism, communism and separatism, were explicitly to be excluded. Within this discourse women were still made representatives of the essentialist metaphor of women as mothers of the pure nation but as the regime developed and the resistance increased, the objectification that women had been subjected to was turning into a subjectification. Women became more politically and socially active and, through the mediation of other different discourses such as feminism, psychoanalysis and post-modernism, they initiated a process of self-understanding in which identity could be seen as plural and partial and different identities could intersect and be allied in individuals and over specific power struggles.

\section{Conclusion}

All the above brings us back to the concept of baroquism. 'Baroque culture, as the culture of the crisis of seventeenth-century absolutism, was diametrically opposed to liberalism and Protestantism, which writers like 
Weber, Mannheim and Parsons have identified with the origins of modern society, modern ideologies and industrial capitalism' (Buci-Glucksmann 1994: 22). It was shown above that the language of nationalism as expressed by Villacañas and others has a baroque component, exemplified by the falangist quotations used in this article. This language is related to the language of absolutism and authoritarianism and is opposed to liberalism. My intention is not to state that the Francoist or falangist discourse consciously invoked the baroque, but rather that certain characteristics of the falangist discourse are similar to some basic baroque concepts. The baroque culture that characterised the Francoist period was a conservative culture, manipulative, traditional, superstitious and religious, based upon concepts of eternity, universality and the divine right of rule. The unitary nature of Francoism as a system of domination is based upon a notion of sameness. Modernity stands for the tradition of the Enlightenment. That was precisely what Francoist ideology was trying to forget, namely the eighteenth and nineteenth centuries, when Spain was not the exporter of a race and a falangist 'way of being'. What Francoist manipulative discourse wanted the nation to remember was the pure Spain cleansed of Jews, Protestants, Muslims and any other community, the Spain known worldwide for its poetry and its Golden Age, a Spain that had become a Patria. In the abovementioned Enciclopedia, in the chapter called 'History of Spain', after quoting that Spain is 'one of the major contributors to world civilisation whose influence in Universal History has been indisputable' (Álvarez 1965: 401), the author adds the statement 'Spain is your Patria.' This Patria is presented as a symbolic place for poetry and purity, as is stated by the following poem, used as the reading for that lesson:

Sweet name that vibrates and shines is the blessed name of patria;

it moves the heart, beats in the idea and lulls to sleep with its magical sound.

Patria is the place where we are born, patria is the corner where we die, the first prayer we learn, the last caress we receive.

Patria is the venerable and saintly land that men always try to beautify; the mother tongue and the first song, the well-made air, the purest light ... Patria is faith, patria is heroism, faith of the martyrs, emblem of the soldier, ribbon of the future that links to the past as a bridge of light over the abyss. (Ávarez 1965: 403, my translation)

Patria in its poetical representation is seen by francoist totalitarian discourse $^{8}$ as a holy, pure, heroic, bright, beautiful space, a symbolic space for a 
contradictory Spain, both diverse and unified, modern and traditional, a Mariolatrous Spain where women appear as an allegory of the nation: rhetorical figures, visual images defined by a quasi-mystical (and baroque) language and unified fragments.

If, finally, baroque could be identified with passion, Francoist Spain once more created a passionate narrative for women that was expressed in baroque style. Perhaps it is this passionate baroquism, and not only the presence but also the active participation of women such as Queen Isabel or Agustina de Aragón and later the women of the SF, that makes Spanish nationalism, under Franco, different from the Italian or German fascist varieties. According to Kaplan (1997: 20-1), 'In all dictatorships, fascist and totalitarian regimes, women were the producers of children, be this to provide cannon fodder (Mussolini), to help "invigorate the race" (Hitler), or to work as servants of men (Salazar, Franco).' European fascism presented itself more as a community of men, in an attempt to continue the mythical military interpretation of manhood into peacetime. In a way, the nation was seen as a camaraderie of men, particularly in Germany with the Nazi Party (Mosse 1985: 174). This masculine dominance threatened to smother women. In the Spanish version of fascism, founded on the falangist ideology, women were also seen as inferior and were excluded and denied recognition because of their sex. The difference perhaps is that this exclusive, baroque and powerful discourse of the feminine came also from within, from the women who were in power. Although there was indeed a great deal of resistance to this power, particularly from the 1960 s, the fact is that, for the women that had to live under the influence of Falange and its feminine branch, Sección Femenina, it was extremely difficult to succeed in their resistance against the regime and they suffered the effects of this power. The grip that this narrative had on women might have been fragile and easily fractured at times, but it had a temporal and spatial ubiquity and its tenacity, sturdiness and persistence in subordinating women meant that women's resistance had very little impact. It was the power of an entangled baroque narrative that shaped Spanish women as a gendered representation of the Spanish nation.

\section{Notes}

1 'New liberalism is an ideology that under different names can be found in many European countries at the turn of the century. It is simply the replacement of the old model of individualistic liberalism by a more socially oriented brand in which state intervention plays an ever-larger role' (Montero 1995: 126).

2 The whole speech can be found in del Río Cisneros 1950: 17-22.

3 The term 'nationalists' or 'nationals' refers to Franco's supporters and it is opposed to 'reds' (rojos) or supporters of the Republic. The use of the word 'nationals' to define the support to the causa nacional (national cause) implies the defence of the 'nation' as one, as opposed to the defence of the different 'nationalities'. However, this idea of the one nation was challenged by Catalans and Basques, for whom democracy and nationalism worked together as a mobilising 
agent. For example, in the case of Catalonia, a number of informal meetings with the representatives of all the political parties started to take place in 1966. Those meetings were called the Taula Rodona (Round Table). In 1969 the Round Table was formalised as the CCFPC, the Co-ordinating Commission of the Political Forces of Catalonia (Comisión Coordinadora de las Fuerzas Politicas de Cataluña) and in 1971 it became the Catalan Assembly (Assemblea de Catalunya), which promoted different activities with a high number of participants (Vilar 1983: 84).

4 All the information about SF comes from the Archive of Alcala de Henares (Madrid). Unfortunately, the material has not been catalogued but is scattered around in different boxes, which make it difficult to find.

5 This marca hispánica is related to the concept of Hispanidad and a certain shared spirituality. As such, this concept should be distinguished from La Marca Hispánica, the territory more or less coinciding with today's Catalonia, which was part of the Frankish empire and gave Catalonia a separate tradition and identity from the rest of the peoples of the Iberian peninsula.

6 Information about the law and all the comments on it may be found in the Archive of Alcala de Henares in box number 27 under the heading 'Spanish themes' (Temas españoles).

7 Francoist discourse about the United States of America was indeed very contradictory. On the one hand, the ideology of La Falange was very explicitly against capitalism and protestantism as two of the main pillars of US society, but, on the other, the United States was seen as a friendly ally in Franco's personal battle against communism. In 1950 the United States recommended Spain to become a member of the United Nations. Spain began to sign agreements with the United States and receive money from them but, at the same time, defended Catholicism and the intervention of the state in every aspect of life.

8 However, the idea of a Patria for all Spaniards did not succeed and was challenged by Catalan and Basque nationalists who took on the mantle of a nationalist and Catholic discourse, beginning their actions in 1959 (Vilar 1983: 67-8).

\section{References}

Alcalde, Carmen. 1996. Mujeres en el franquismo. Barcelona: Flor de Viento.

Álvarez. 1965. Enciclopedia. Intuitiva, Sintética y práctica. Tercer Grado. Valladolid: Miñón.

Boyd, Catherine. 1997. Historia Patria. Politics, History and National Identity in Spain, 1875-1975. Princeton NJ: Princeton University Press.

Brinker-Gabler, Gisela and Sidonie Smith (eds.). 1997. Writing New Identities. Gender, Nation, and Immigration in Contemporary Europe. MN: University of Minnesota Press, Minneapolis.

Buci-Gluksmann, Christine. 1994. Baroque Reason. The Aesthetics of Modernity. London: Sage.

Caldwell, Lesley. 1989. 'Women as the family: the foundation of a new Italy?' in Nira Yuval-Davis and Floya Anthias (ed.), Women-State-Nation. London: Macmillan.

Castro Villacañas, Antonio. 1948. La Hora, 14 May.

Carbayo-Abengózar, Mercedes. 1998. Buscando un lugar entre mujeres: Buceo en la España de Carmen Martín Gaite. Málaga: Málaga University Press.

Enciso, E. 1967. La muchacha en el noviazgo. 9th edn. Madrid: Studium.

Fernández Cuesta, Raimundo. 1974. 'La Falange. Síntesis de valores', El Alcázar, 26 November: $1-8$.

Foucault, Michel. 1980. 'Two lectures' in C. Gordon (ed.), Power/Knowledge: Selected Interviews and Other Writings 1972-1977 by Michel Foucault. London: Harvester Wheatsheaf, 78-109.

Foucault, Michel. 1982. 'The subject and power' in Hubert Dreyfus and Paul Rabinow (eds.), Michel Foucault: Beyond Structuralism and Hermeneutics. Chicago: University of Chicago Press, 208-26.

Foucault, Michel. 1984. The History of Sexuality. Vol. I: An Introduction. London: Penguin.

García Basauri, Mercedes. 1980. 'La Sección Femenina en la guerra civil española', Historia 16, 50: $45-56$. 
García de Cortázar, Fernando and José Manuel González Vesga. 1994. Breve historia de España. Madrid: Alianza Editorial.

Graham, Helen and Jo Labanyi (eds.). 1995. Spanish Cultural Studies. Oxford: Oxford University Press.

Graham, Helen. 1995. 'Women and social change' in Helen Graham and Jo Labanyi (eds.), Spanish Cultural Studies. An Introduction. Oxford: Oxford University Press, 99-116.

Guibernau, Montserrat. 1996. Nationalisms. The Nation-state and Nationalism in the Twentieth Century. Cambridge: Polity Press.

Hall, Stuart. 1992. 'New ethnicities' in J. Donald and A. Rattansi (eds.), 'Race', Culture and Difference. London: Sage, 252-60.

Hastings, Adrian. 1997. The Construction of Nationhood. Ethnicity, Religion and Nationalism. Cambridge: Cambridge University Press.

Hutchinson, John and Anthony D. Smith. 1994. Nationalism. Oxford: Oxford University Press. Kaplan. Gisela. 1992. Contemporary Western Europe Feminism. London: Allen and Unwin.

Kaplan. Gisela. 1997. 'Feminism and nationalism: the European case' in Lois A. West (ed.), Feminist Nationalism. London: Routledge.

Manjón, Manuales. 1940. Breve resumen con dos gráficos. 14th edn. Granada: Imprenta-Escuela de Ave María.

Martín, Denis-Constant. 1995. 'The choices of identity' Social Identities, 1(1): 5-16.

Mercer, Kubena. 1990. 'Welcome to the jungle: identity and diversity in postmodern politics' in J. Rutherford (ed.), Identity, Community, Culture, Difference. London: Lawrence and Wishart, 43-72.

Montero, Enrique. 1995. 'Reform idealized: the intellectual and ideological origins of the Second Republic' in Helen Graham and Jo Labanyi (eds.), Spanish Cultural Studies. An Introduction. Oxford: Oxford University Press, 124-33.

Morcillo, Aurora. 1988. 'Por la senda del franquismo', Historia 16 145: 86-90.

Mosse, George. 1985. Nationalism and Sexuality: Middle-class Morality and Sexual Norms in Modern Europe. New York: Howard Fertig.

Parker, Andrew et al. (eds). 1992. Introduction to Nationalisms and Sexualities. New York: Routledge.

Payne, Stanley. 1984. Spanish Catholicism. An Historical Overview. Madison, WI: Wisconsin University Press.

Payne, Stanley. 1992. 'El hábil uso de las familias del régimen', El País, 3 December: 10-11.

Peterson, Spike. 1996. 'The politics of identification in the context of globalization', Women's Studies International Forum 19: 5-16.

Puga, A. 1969. Historia de la Falange. Barcelona: Dopesa.

Richards, Michael. 1995. 'Autarky and the Franco dictatorship in Spain, 1936-1945' cited in Claire Mar Molinero and Ángel Smith (eds.), Nationalism and the Nation in the Iberian Peninsula. Oxford: Berg, p. 151.

Río Cisneros, Agustín del. 1950. Obras completas de José Antonio Primo de Rivera. Madrid: Publicaciones de la Dirección General de Propaganda.

Scanlon, Geraldine. 1986. La polémica feminista en la España contemporánea 1868-1974. Madrid: Akal.

Semanario 'Consúltame'. 1944. Medina. Semanario de la Sección Femenina.

Thomàs, José María. 1999. Lo que fue la Falange. Barcelona: Plaza y Janés.

Tuñón de Lara, Manuel. 1982a. 'La II República', Historia 16, 11: 61-129.

Tuñón de Lara, Manuel. 1982b. 'La España de Franco. La sociedad y sus instituciones', Historia 16, 12: 110-30.

Verdú, Vicente. 1986. 'Amor y sexualidad en España', Historia 16, 24: 11-81.

Vilar, Sergio. 1983. 'La oposición a la dictadura franquista', Historia 16 13: 61-89. 